\title{
Behavioural Aspects of Light Gauge Steel Section with Different Cross Sections
}

\author{
K. Sathish Kumar, Venkat Raman S, Arunya A
}

\begin{abstract}
Light Gauge steel structures are auxiliary items that are made by framing plane sheets of steel at an encompassing temperature into various shapes that can be utilized to fulfill basic and utilitarian prerequisites. As of late, the interest for high quality materials for wide scope of auxiliary applications has been instrumental for more improvements in cool shaped steel areas when contrasted with the hot moved steel segments. Along these lines, the comprehension of cold shaped steel execution turns into a significant issue to be examined. This paper holds three works. In the first place, it audits a presentation on cool shaped steel structures. Second, it abridges exceptional structure criteria and nearby clasping and post clasping quality of cold framed steel developments. At long last, it offers an end on the requirement for creative sectional profiles over the traditional areas for cold shaped steel.
\end{abstract}

Keywords - Steel Structures, Cold Frame Steel, Light guage steel

\section{INTRODUCTION}

\section{A. General}

Basic steel individuals are broadly utilized in structures, for example, spans, rooftop supports, transmission line towers, multistoried structures and so forth., in view of its high solidarity to weight proportion, bringing about the decrease of dead weight.

The two principle gatherings of auxiliary steel individuals are hot-moved steel individuals and cold-shaped steel individuals[1]-[4].

Lately, chilly shaped steel areas have increased significant noticeable quality over hot-moved segments. Two primary reasons credited to the above certainty are, their economy accomplished for generally light burden under moderate ranges and their sectional setups, which gives a decision to the modelers and originators.

\section{B. Cold Frame Steel}

The idea of cold-shaped auxiliary steel items began in the western world. The fundamental procedure of cold-shaped steel auxiliary components includes framing steel areas in a virus state from steel sheets of uniform thickness. The thickness of steel individuals ranges from $0.4 \mathrm{~mm}$ to $6.4 \mathrm{~mm}$. The virus shaping activity expands the yield point and a

Revised Manuscript Received on October 22, 2019.

K. Sathish Kumar, Department of Civil Engineering, Bharath Institute of Higher Education and Research, Chennai, India. Email: sathish_4549@yahoo.co.in

Venkat Raman S, Department of Civil Engineering, Bharath Institute of Higher Education and Research, Chennai , India. Email: mailmagik@yahoo.com

Arunya A, Department of Civil Engineering, Bharath Institute of Higher Education and Research, Chennai , India. Email: arunyaaaa@gmail.com definitive quality of the steel segments. Their huge solidarity to weight proportion, flexibility, non instability without breaking a sweat of generation has pulled in draftsmen, specialists, developers and makers of building items with the guarantee, that it can assist them with giving improved capacity and more prominent tasteful appearance for some applications requiring little to no effort .

The wide scope of accessible cold-shaped steel items has extended their utilization to essential shafts, floor units, rooftop brackets, divider boards and building outlines. Cold-framed steel individuals can be created in a wide assortment of sectional profiles, for example, points, channels, cap segments, zed segments and sigma segments. Points are the most well-known basic shape found in practically any structure because of their straightforwardness and simplicity of creation and erection. Single points are normally utilized as web individuals in steel joists and brackets, individuals from latticed transmission towers or correspondence structures and furthermore as propping individuals to give sidelong support to the principle individuals[5]-[8].

Coal is the result of a large number of long periods of deteriorating vegetable issue under strain, and its substance arrangement is inconsistent. What's more, electric organizations advance power creation from coal utilizing added substances, for example, pipe gas conditioners, sodium sulfate, oil, and different added substances to control consumption, outflows, and fouling[9]-[12]. The subsequent fly debris can have a variable organization and contain a few added substances just as items from inadequate burning.

\section{B. Types of Section}

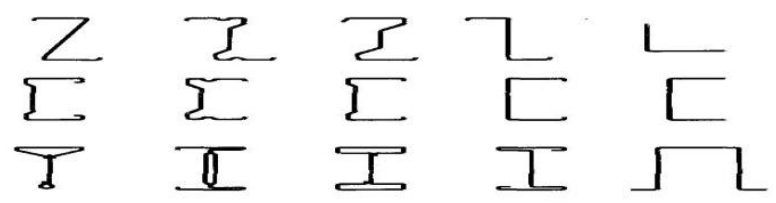

a) Single open Sections

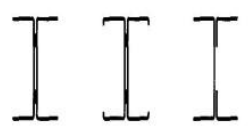

b) Open Build up Sections

Published By:

Blue Eyes Intelligence Engineering 

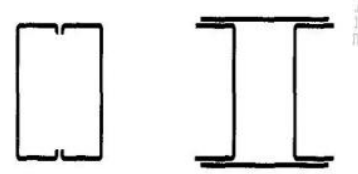

c) Open Build up Sections

\section{Manufacturing}
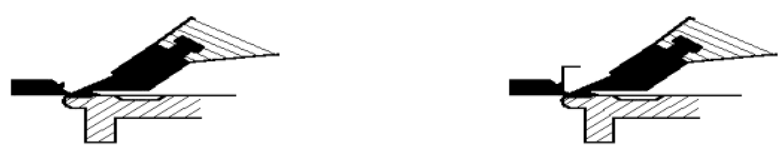

1
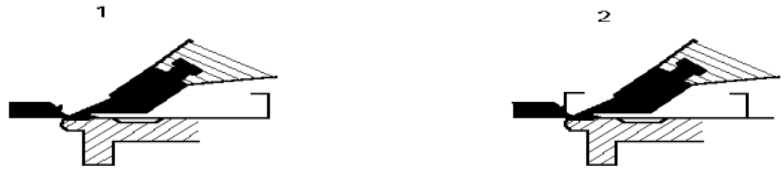

Figure 5 Manufacturing by folding

a) Folding

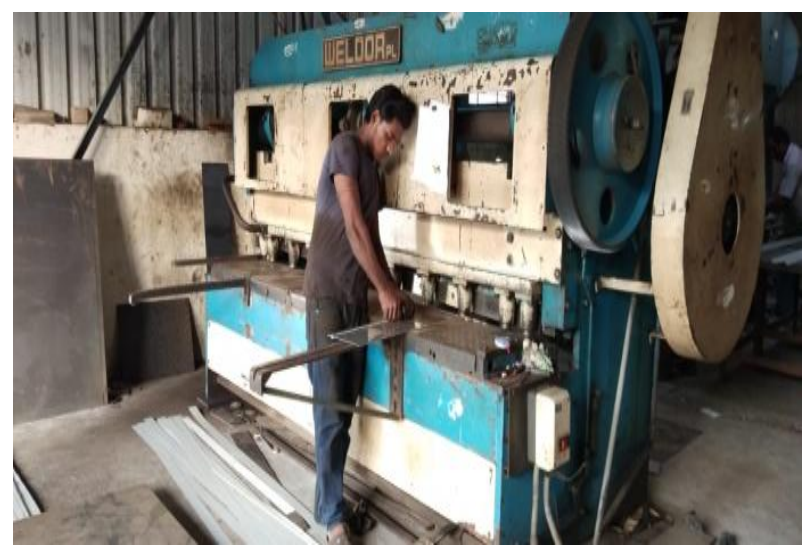

b) Press breaking

D. Advantage And Disadvantage Of Cold Formed Section

Advantage: -

- Strength

- Durable

- Non-combustible

- Sustainable

- Cost-effective

- Light weight

\section{Disadvantage:}

- Low fire resistance

- Unit price

- Careful requirement

- Difficult connecting

- Thermal and sound insulation

\section{METHODOLOGY}

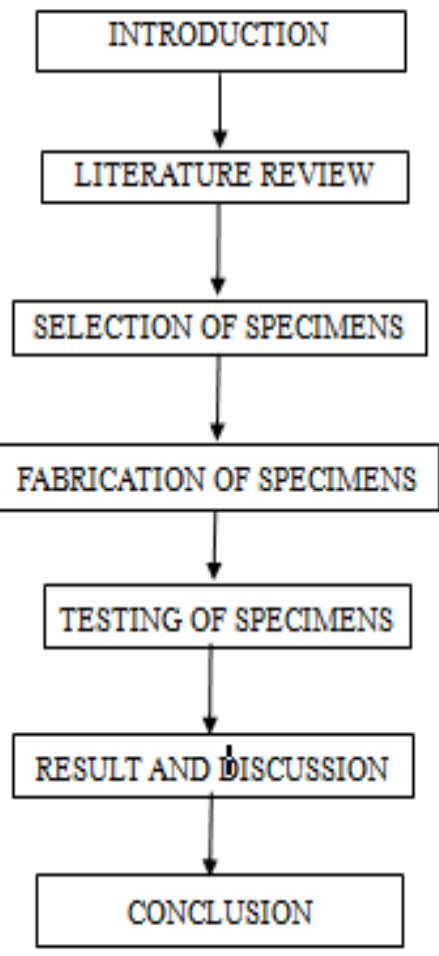

\section{A. Selection of Specimens}

In this experiment we will take four different types of cold formed section

- Channel section

- Channel section with lips

- Rectangular section

- I-section

With the help of code book IS:801(1975) and IS:811(1987) we will going to perform this experiment. The thickness of section is $2 \mathrm{~mm}$ which is taken from code book.

\section{B. Channel Section}

The basic channel otherwise called C-Channel or parallel spine channel (PFC) is sort of pillar utilized fundamentally in building development and structural designing. It's cross area comprise of a wide "web" for the most part yet not constantly arranged vertically, and two "spines" at the top and base of the web[13]-[17].

\section{RESULTS AND DISCUSSIONS}

\section{A. Design Paremeters Of The Section}

- Overall span length (L) $=1.5 \mathrm{~m}$

- Height (h) = $100 \mathrm{~mm}$

- Width (b) $\quad=40 \mathrm{~mm}$

- Thickness $(\mathrm{t}) \quad=2 \mathrm{~mm}$

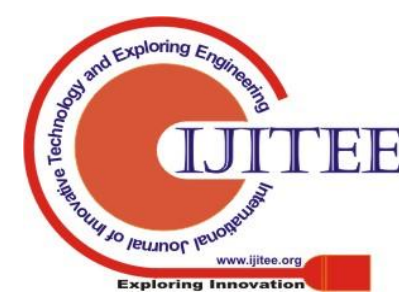




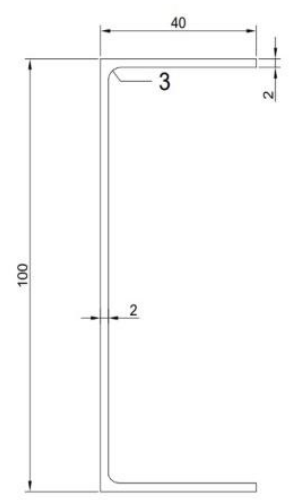

Fig - 1 Channel Section

\section{B. Channel Section With Lips}

Lip channel are overwhelmingly utilized as a basic segments when raising or developing structure and structures this has likewise lead to lip channels very get being alluded to as purlins.

\section{Design Paremeters of The Section}

- Overall span length $(\mathrm{L}) \quad=1.5 \mathrm{~m}$

- Height (h)

$$
=100 \mathrm{~mm}
$$

- Width (b)

$=40 \mathrm{~mm}$

- Thickness (t)

$=2 \mathrm{~mm}$

- Lips

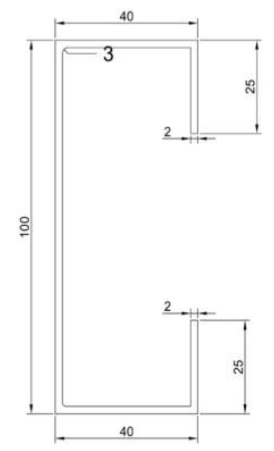

Fig - 2 Channel Section with Lips

\section{Rectangular Section}

In for the most part rectangular implies that figure whose contrary sides are equivalent and points between lines are $90^{\circ}$ and segments basically implies cutted divide.

\section{Design Paremeters Of The Section}

- Overall span length (L) $=1.5 \mathrm{~m}$

- Height (h)

$$
=100 \mathrm{~mm}
$$

- Width (b)

- Thickness (t)

$$
=80 \mathrm{~mm}
$$

$$
=2 \mathrm{~mm}
$$

\section{I Section}

The even components of the "I-segment" are known as spine, while the vertical components is named the web I-pillar are normally made of auxiliary steel and are utilized in development and structural designing. The web opposes shear power while the rib oppose the vast majority of the bowing minute[18]-[22].

\section{Design Paremeters Of The Section}

$$
\begin{aligned}
& \text { - Overall span length (L) } \quad=1.5 \mathrm{~m} \\
& \text { - Height (h) =100mm } \\
& \text { - Width (b) } \quad=80 \mathrm{~mm} \\
& \text { - } \text { Thickness }(\mathrm{t}) \quad=2 \mathrm{~mm}
\end{aligned}
$$

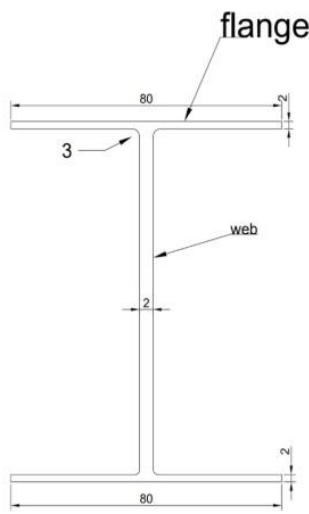

$$
\text { Fig - } 4 \text { I Section }
$$

The erection of I-section is done by joining two channel section in opposite direction with the help of welding and it's also known as built up section.

The erection of rectangular section is done by joining two channel section in same direction with the help of welding and it's also known as built up section. 


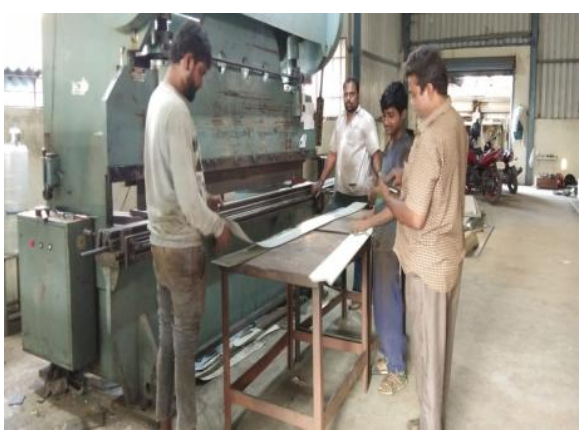

\section{E. Working Principles}

It is completely robotized using pressurized water worked general testing machine which acknowledged simplicity of-activity. It comprise of high exactness electronic control board which consolidating control, optics, sensors and data handling[23]-[26]. It is PC worked perfect Trapezium Software which gives streamlined client activity wizards and the business head route framework. This machine is valuable to test any material which is exposed to pressure and pressure, for example, steel bars, HT strands, Mechanical Couplers, Foundation jolts, Concrete Cubes and Cylinders and Concrete Beams. This machine likewise worked at various scales according to necessity, for example, $20 \mathrm{kN}, 40 \mathrm{kN}, 100 \mathrm{kN}$, $200 \mathrm{kN}, 400 \mathrm{kN}, 1000 \mathrm{kN}$ upto its full limit for example $2000 \mathrm{kN}$. Diverse kind of Extensometer is utilized to gauge the stretching and modulus of flexibility of steel and cement individually.

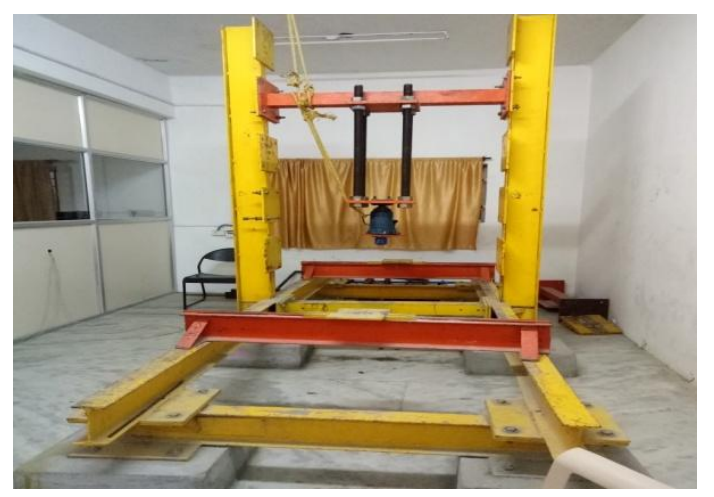

Compression Strength Cubes, Flexural Strength of Beams, Modulus of Elasticity in Cylinders of concrete

\section{F. User Instructions}

- Attention should be exercised when attaching/detaching the specimen, installing/uninstalling the test equipment, or operating the load frame associated with that work.

- Be sure to raise or lower the lower crosshead while checking that no interfering object exists between the lower crosshead and table or above the lower crosshead[27]-[30].

- Install protective cover depending on the shape of the specimen to prevent broken pieces of the specimen from flying off.

- In tensile tests, attach the grip jaw holder so that its entire length makes contact with the internal surface of the crosshead.
- In compression tests, do not apply a face pressure of $200 \mathrm{~N} / \mathrm{mm}^{2}$ or greater to the platens. Do so may cause damage to the platens.

- Check the position of the limit switch before test.

We have taken four different types of cold formed steel section.

\section{CHANNEL SECTION \\ CHANNEL SECTION WITH LIPS \\ RECTANGULAR SECTION \\ I-SECTION}

A) Channel Section
\begin{tabular}{|r|r|r|}
\hline \multicolumn{1}{|l|}{ LOAD } & LVDT \\
\hline 0.05 & 1.453 \\
\hline 0.1 & 2.537 \\
\hline 0.15 & 3.665 \\
\hline 0.2 & 4.867 \\
\hline 0.25 & 6.038 \\
\hline 0.3 & 7.718 \\
\hline 0.35 & 9.745 \\
\hline 0.4 & 11.77 \\
\hline 0.37 & 12.324 \\
\hline 0.35 & 13.001 \\
\hline
\end{tabular}

It bear highest load is 0.40Tone and its highest deflection is $11.77 \mathrm{~mm}$

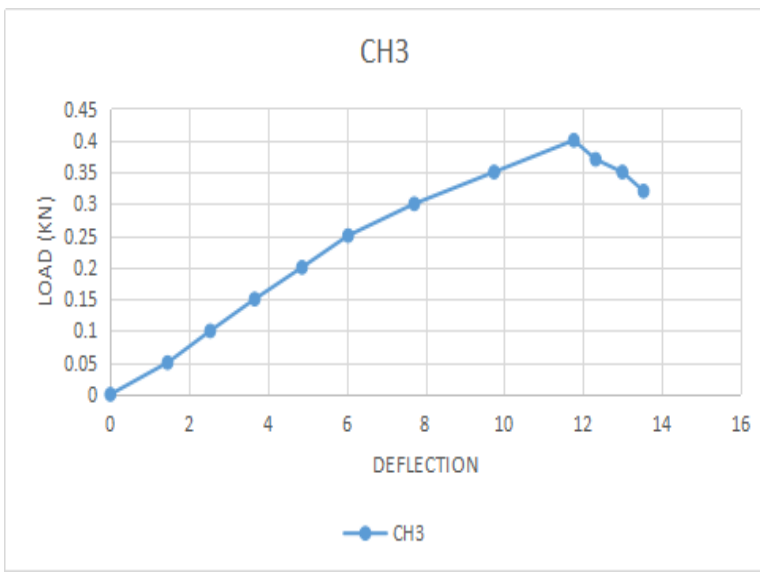

B) Channel Section with lips 


\begin{tabular}{|r|r|}
\hline LOAD & LVDT \\
\hline 0 & 0 \\
\hline 0.05 & 0.604 \\
\hline 0.1 & 1.268 \\
\hline 0.15 & 1.953 \\
\hline 0.2 & 2.971 \\
\hline 0.25 & 3.717 \\
\hline 0.3 & 4.841 \\
\hline 0.35 & 6.178 \\
\hline 0.4 & 8.902 \\
\hline 0.37 & 7.805 \\
\hline 0.35 & 6.568 \\
\hline
\end{tabular}

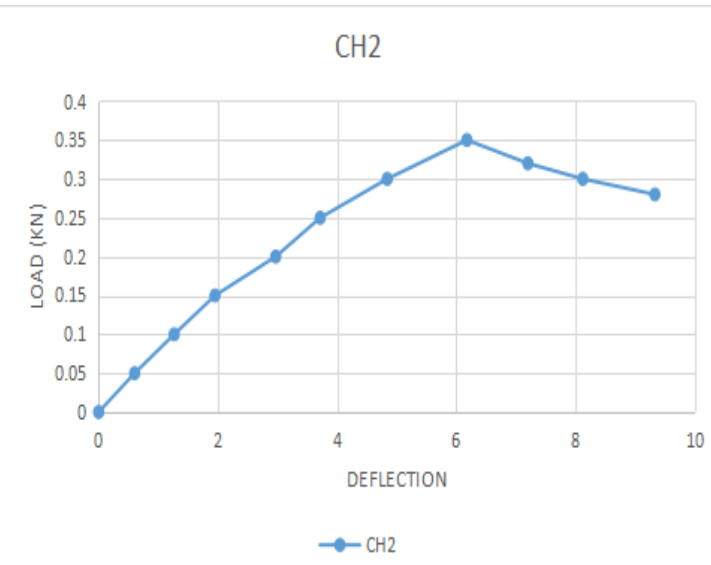

It bear highest load is 0.40 Tone and its highest deflection is $8.902 \mathrm{~mm}$.

\section{C) Rectangular Section}

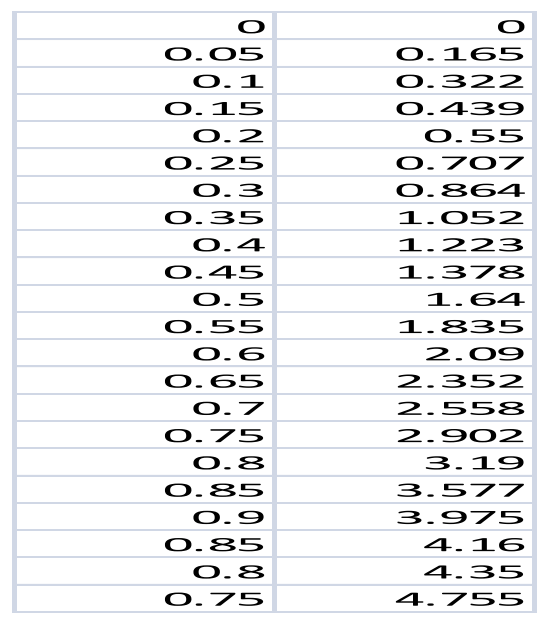

It bear highest load is 0.9 Tone and its highest deflection is $3.975 \mathrm{~mm}$.

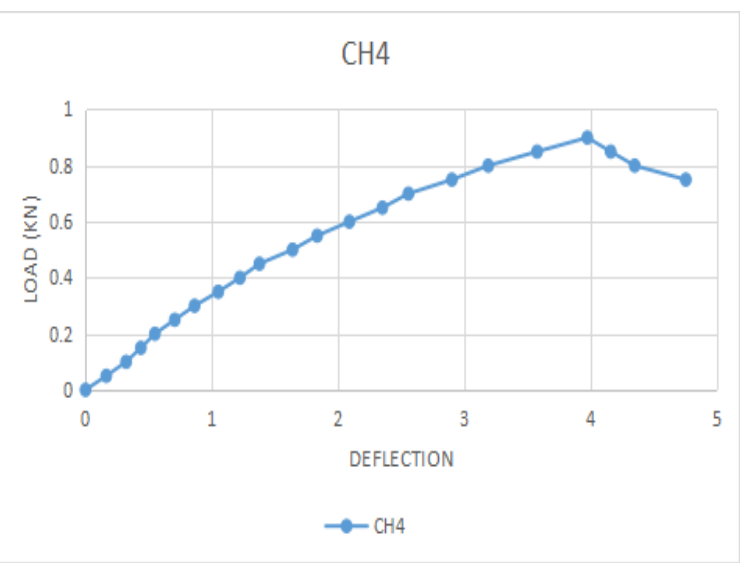

After comparing all the channel section we see that I-Section bear more load and having less deflection. So it is more suitable for the construction[31]-[34].

\section{CONCLUSION}

$>$ From above the experimental investigation it is observed that cold formed section I section exhibited satisfactory performance in compare with all other section.

$>$ The failure mode of beam involved in local buckling and lateral torsional buckling.

$>$ Cold formed I -section takes more load and compare to all other cold formed section.

$>$ The properties of cold formed with various cross section were studied.

\section{REFERENCES}

1. Iyappan L., Dayakar P., Identification of landslide prone zone for coonoortalukusing spatial technology, International Journal of Applied Engineering Research,V-9,I-22,PP-5724-5732,Y-2014.

2. Kumar J., Sathish Kumar K., Dayakar P.,Effect of microsilica on high strength concrete, International Journal of Applied Engineering Research,V-9,I-22,PP-5427-5432,Y-2014

3. Dayakar P., Vijay Ruthrapathi G., Prakesh J., Management of bio-medical waste, International Journal of Applied Engineering Research,V-9,I-22,PP-5518-5526,Y-2014

4. Swaminathan N., Dayakar P., Resource optimization in construction project, International Journal of Applied Engineering Research,V-9,I-22,PP-5546-5551,Y-2014

5. Venkat Raman K., Dayakar P., Raju K.V.B.,An experimental study on effect of cone diameters in penetration test on sandy soil, International Journal of Civil Engineering and Technology,V-8,I-8,PP-1581-1588,Y-2017.

6. Saritha B., Chockalingam M.P.,Photodradation of malachite green DYE using TIO2/activated carbon composite, International Journal of Civil Engineering and Technology,V-8,I-8,PP-156-163,Y-2017

7. Shendge R.B., Chockalingam M.P., Saritha B., Ambica A.,Swat modelling for sediment yield: A case study of Ujjani reservoir in Maharashtra, India,International Journal of Civil Engineering and Technology,V-9,I-1,PP-245-252,Y-2018

8. Chockalingam M.P., Balamurgan V.,Modernisation of an existing urban road-sector in Chennai, a case study report,International Journal of Civil Engineering and Technology,V-8,I-8,PP-1457-1467,Y-2017

9. Saritha B., Chockalingam M.P.,Adsorption study on removal of basic dye by modified coconut shell adsorbent, International Journal of Civil Engineering and Technology,V-8,I-8,PP-1370-1374,Y-2017

10. Saritha B., Chockalingam M.P.,Adsorptive removal of heavy metal chromium from aqueous medium using modified natural adsorbent,International Journal of Civil Engineering and Technology,V-8,I-8,PP-1382-1387,Y-2017

11. Chockalingam M.P., Palanivelraja S.,Retrospective analysis of a theoretical model used for forecasting future air quality near the north Chennai thermal

power 
plant,International Journal of Civil Engineering and Technology,V-8,I-8,PP-1457-1467,Y-2017

12. Saritha B., Chockalingam M.P.,Photodegradation of methylene blue dye in aqueous medium by $\mathrm{Fe}-\mathrm{AC} / \mathrm{TiO} 2$ Composite,Nature Environment and Pollution Technology,V-17,I-4,PP-1259-1265,Y-2018

13. Shendge R.B., Chockalingam M.P., Kaviya B., Ambica A.,Estimates of potential evapotranspiration rates by three methods in upper Bhima Basin, In Maharashtra, India,International Journal of Civil Engineering and Technology,V-9,I-2,PP-475-480,Y-2018

14. Shendge R.B., Chockalingam M.P.,The soil and water assessment tool for Ujjani Reservoir,International Journal of Mechanical Engineering and Technology,V-9,I-2,PP-354-359,Y-2018

15. Shendge R.B., Chockalingam M.P.,A review on soil and water assessment tool,International Journal of Mechanical Engineering and Technology,V-9,I-2,PP-347-353,Y-2018

16. Sachithanandam P., Meikandaan T.P., Srividya T.,Steel framed multi storey residential building analysis and design,International Journal of Applied Engineering Research,V-9,I-22,PP-5527-5529,Y-2014

17. Meikandaan T.P., Ramachandra Murthy A.,Study of damaged RC beams repaired by bonding of CFRP laminates, International Journal of Civil Engineering and Technology,V-8,I-2,PP-470-486,Y-2017

18. Meikandaan T.P., Ramachandra Murthy A.,Retrofittng of reinforced concrete beams using GFRP overlays,International Journal of Civil Engineering and Technology,V-8,I-2,PP-423-439,Y-2017

19. Meikandaan T.P., Ramachandra Murthy A.,Flexural behaviour of RC beam wrapped with GFRP sheets,International Journal of Civil Engineering and Technology,V-8,I-2,PP-452-469,Y-2017

20. Meikandaan T.P., Murthy A.R.,Experimental study on strengthening of rc beams using glass Fiber.International Journal of Civil Engineering and Technology,V-9,I-11,PP-959-965,Y-2018

21. Meikandaan T.P., Hemapriya M.,Use of glass FRP sheets as external flexural reinforcement in RCC Beam,International Journal of Civil Engineering and Technology,V-8,I-8,PP-1485-1501,Y-2017

22. Saraswathy R., Saritha B.,Planning of integrated satellite township at Thirumazhisai,International Journal of Applied Engineering Research,V-9,I-22,PP-5558-5560,Y-2014

23. Saritha B., Ilayaraja K., Eqyaabal Z.,Geo textiles and geo synthetics for soil reinforcement,International Journal of Applied Engineering Research,V-9,I-22,PP-5533-5536,Y-2014

24. Ambica A., Saritha B., Changring G., Singh N B., Rajen M., Salman Md.,Analysis of groundwater quality in and around Tambaram taluk, Kancheepuram district,International Journal of Civil Engineering and Technology,V-8,I-8,PP-1362-1369,Y-2017

25. Arunya A., Sarayu K., Ramachandra Murthy A., Iyer N.R.,Enhancement of durability properties of bioconcrete incorporated with nano silica,International Journal of Civil Engineering and Technology,V-8,I-8,PP-1388-1394,Y-2017

26. Ilayaraja K., Krishnamurthy R.R., Jayaprakash M., Velmurugan P.M., Muthuraj S.,Characterization of the 26 December 2004 tsunami deposits in Andaman Islands (Bay of Bengal, India),Environmental Earth Sciences,V-66,I-8,PP-2459-2476,Y-2012

27. Ilayaraja K.,Morphometric parameters of micro watershed in Paravanar sub-basin, Cuddalore District,International Journal of Civil Engineering and Technology,V-8,I-8,PP-1444-1449,Y-2017

28. Ilayaraja K., Singh R.K., Rana N., Chauhan R., Sutradhar N.,Site suitability assessment for residential areas in south Chennai region using remote sensing and GIS techniques,International Journal of Civil Engineering and Technology,V-8,I-8,PP-1468-1475,Y-2017

29. Ilayaraja K., Reza W., Kumar V., Paul S., Chowdhary R.,Estimation of land surface temperature of Chennai metropolitan area using Landsat images,International Journal of Civil Engineering and Technology,V-8,I-8,PP-1450-1456,Y-2017

30. Chitra R.,Experimental study on beam using steel fiber and latex,International Journal of Civil Engineering and Technology,V-8,I-8,PP-1395-1403,Y-2017

31. Chitra R.,Analysis of traffic and management at Kovilambakkam intersection,International Journal of Civil Engineering and Technology,V-8,I-8,PP-1433-1443,Y-2017

32. Aswathy M.,Experimental study on light weight foamed concrete,International Journal of Civil Engineering and Technology,V-8,I-8,PP-1404-1412,Y-2017

33. Aswathy M.,Wastewater treatment using constructed wetland with water lettuce (Eichornia Crasipies),International Journal of Civil Engineering and Technology,V-8,I-8,PP-1413-1421,Y-2017

34. Kiruthiga K., Anandh K.S., Gunasekaran K, Assessment of influencing factors on improving effectiveness and productivity of construction engineers, 2015, International Journal of Applied Engineering Research, V - 10,I -17,p -13849-13854.

\section{AUTHORS PROFILE}

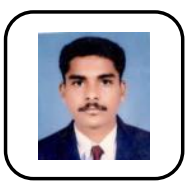

K. Sathish Kumar, Assistant Professor, Department of Civil Engineering, Bharath Institute of Higher Education and Research, Chennai, India.

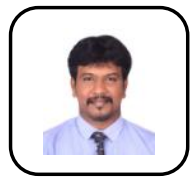

Venkat Raman S , Assistant Professor, Department of Civil Engineering, Bharath Institute of Higher Education and Research, Chennai , India

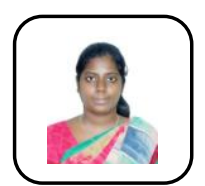

Arunya A, Assistant Professor, Department of Civil Engineering, Bharath Institute of Higher Education and Research, Chennai, India. 